\title{
Variability in foraging in response to changing prey distributions in rhinoceros auklets
}

\author{
Gail K. Davoren* \\ University of Victoria, Department of Biology, PO Box 1700, Victoria, British Columbia V8W 2Y2, Canada
}

\begin{abstract}
Variable time budgets and foraging behaviour were observed in a marine diving bird, the rhinoceros auklet Cerorhinca monocerata, in response to intraseasonal and interannual variations in prey abundance and distribution. Few studies have simultaneously measured the spatial dispersal of seabirds at sea, time budgets at sea and prey abundance and distribution. Time budgets and foraging behaviour were determined through visual scans. Prey abundance, estimated hydroacoustically during marine transects, was similar among years, but prey was dispersed over larger spatial areas in 1997 than in 1995 and 1996. Rhinoceros auklets were also dispersed over larger spatial areas in 1997 and fewer mixed-species feeding flocks were formed. In 1997, rhinoceros auklets increased the time spent foraging, decreased the recovery periods between successive dives, and were more strongly associated with prey at larger spatial scales. This suggested that auklets were working hard while foraging but were less successful at locating and maintaining contact with prey when prey was more dispersed. In 1996, there was a period (June 13 to 20) when fish schools were common near the surface, during which auklets spent more time foraging and formed more feeding flocks. This suggested that auklets were working hard to take advantage of this readily available prey. This paper illustrates the importance of behavioural plasticity and time budget flexibility for seabirds living in highly variable environments.
\end{abstract}

KEY WORDS: Seabirds · Time budgets · Risk-sensitive foraging behaviour · Predator-prey interactions

\section{INTRODUCTION}

Animals that feed on patchily distributed prey, which change constantly in quality and location, may have problems maintaining current information on all prey patches in an area (McNamara \& Houston 1985, Shettleworth et al. 1988). To deal with this problem, animals presumably must sample areas on a regular basis (Shettleworth et al. 1988) or rely on cues from other foragers (Burger 1997). When prey becomes more difficult to locate in an area, either through changing distribution or abundance, animals must increase the time spent foraging or alter their foraging behaviour.

Some seabirds are known to increase the time spent foraging at sea and decrease the time spent resting at

\footnotetext{
-Present address: Biopsychology Programme, Departments of Biology \& Psychology, Memorial University of Newfoundland, St. John's, Newfoundland A1B 3X9, Canada.

E-mail: z73gkd@morgan.ucs.mun.ca
}

the colony under poor foraging conditions (Burger \& Piatt 1990, Monaghan et al. 1996). The amount of time spent resting in daily time budgets reflects the ability of an animal to increase the time spent foraging under varying foraging conditions (Herbers 1981, Southern \& Moss 1985). 'Resting' is hard to define because animals may appear to be resting but instead are engaged in important maintenance activities, such as digestion. Therefore, an animal may appear to have spare time but really is unable to alter its time budget. Whether animals can adjust their time budgets, how they adjust and the costs of these adjustments are critical in determining whether animals can buffer the deleterious effects of changing foraging conditions on breeding success and ultimately on their own survival.

Seabirds also may be able to buffer the effects of changing foraging conditions by altering their foraging behaviour. Seabirds forage solitarily or in groups such as mixed-species feeding flocks of seabirds that form over concentrations of fish or zooplankton (Hoffman et al. 1981, Porter \& Sealy 1981, 1982, Harrison et al. 
1991). Group foraging primarily involves monitoring the foraging behaviour of other animals in the vicinity and, thus, increases each individual's search efficiency and subsequent encounter rates with prey compared to solitary foraging (Wittenberger \& Hunt 1985). Group foraging, however, is only advantageous under certain conditions. Predators generally benefit from foraging in a group when food is patchily distributed and the prey aggregation is sufficiently large to fulfill the requirements of all group members. The trade-off between increased encounter rates with prey via group foraging and reduced encounter rates with prey via competition among group members changes as prey characteristics change.

Few studies have simultaneously measured the spatial dispersal of seabirds at sea, time budgets at sea and prey abundance and distribution. The objectives of this study were to describe the variability in time budgets and foraging behaviour of a marine diving bird, the rhinoceros auklet Cerorhinca monocerata, in response to intraseasonal and interannual fluctuations in prey abundance and distribution. This bird mainly feeds on small, epi-pelagic, schooling fish (Gaston \& Dechesne 1996), whose abundance can be highly variable both temporally and spatially. The ability to adjust time budgets and foraging behaviour (behavioural flexibility) will therefore be important for animals feeding on prey with these characteristics and will reflect an animal's ability to buffer the effects of varying environmental conditions.

\section{METHODS}

Marine transects. Prey abundance was estimated in repeated marine transects through the rhinoceros auklet's breeding season (mid-May to early September) in 1996 and during the chick-rearing phase (mid-June to mid-August) in 1995 and 1997. A fixed transect $(\sim 25 \mathrm{~km})$ was conducted in the morning in small boats ( 4 to $6 \mathrm{~m}$ ) near the Seabird Rocks breeding colony $\left(48^{\circ} 45^{\prime} \mathrm{N}, 125^{\circ} 09^{\prime} \mathrm{W} ;\right.$ Fig. 1). The transect route inten-

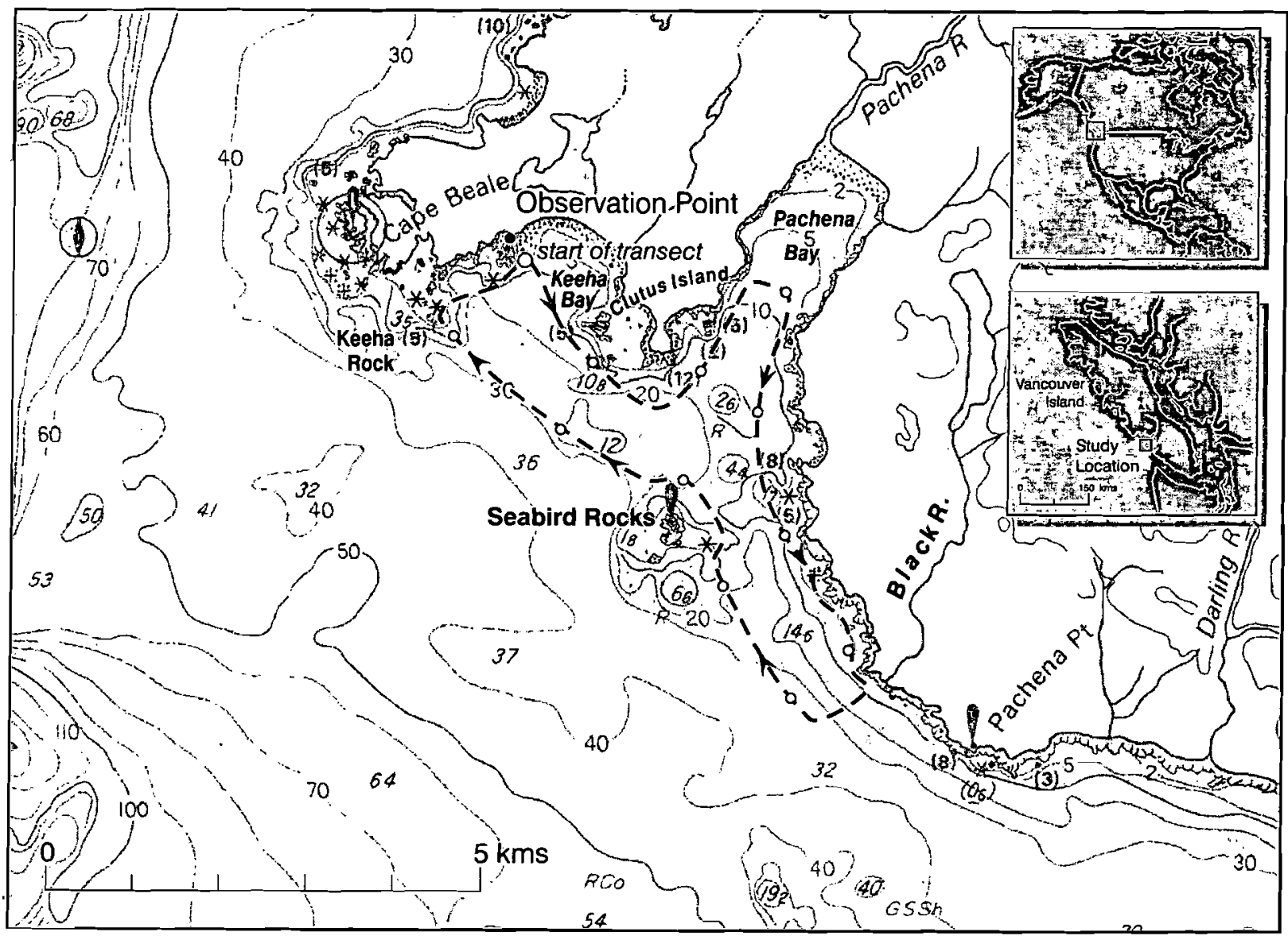

Fig. 1. Map of study атеa, indicating the point from which observation scans were conducted (observation point), the transect route and the Seabird Rocks breeding colony of rhinoceros auklets 
sively sampled the main foraging area of auklets (Davoren 1997). Bird numbers and prey abundance were recorded simultaneously every $20 \mathrm{~s}(\sim 100 \mathrm{~m})$ along the transect. Standardized transect procedures were used where birds were recorded within $150 \mathrm{~m}$ on both sides of the boat (Tasker et al. 1984). Prey was recorded using a $200 \mathrm{kHz}$ echosounder that printed a chart record (echogram). The gain and sample depth of the echosounder ( 1 to $40 \mathrm{~m}$ ), along with boat speed $\left(18 \mathrm{~km} \mathrm{~h}^{-1}\right)$, were held constant in all acoustic surveys.

Prey abundance was quantified by estimating the percentage cover of the prey image in each $100 \mathrm{~m}$ horizontal block on the echogram (Piatt 1990). This was translated into a prey abundance score (scale 0 to 9 ), which was squared prior to analysis to attain a better estimate of relative abundance (Piatt 1990). Based on previous experience, distinguishing between schools of small fish or euphausiids and solitary, large fish on the echogram was straightforward (Fig. 2). I also conducted field tests to discriminate between schools of euphausiids and schools of small fish on the echogram. This involved driving over a school at the ocean's surface, where I netted $(n=19)$ or visually identified $(n=16)$ the species composition and recorded the school on the echosounder. All of the netted and observed schools consisted of juvenile Pacific sand lance Ammodytes hexapterus and juvenile Pacific herring, Clupea harengus. Most of the schools observed on the echograms (94\%) resembled the echograms of these juvenile fish; the other $6 \%$ of the schools were excluded from the analysis.

Analysis of transect data. Mean prey abundance for each transect was calculated by averaging the squared prey abundance scores over all $100 \mathrm{~m}$ blocks. This relative measure of prey abundance was compared among years using a single-factor ANOVA for unbalanced designs and Scheffe's multiple comparisons test (Sokal \& Rohlf 1995). Similarly, the total number of rhinoceros auklets observed in each transect was compared among years.

I used univariate neighbourhood $K$ statistics to assess whether the distribution of auklets and prey separately along each transect was significantly different from random at a number of spatial scales (see O'Driscoll 1998). For each transect, I calculated the expected number of neighbours of any given auklet or prey patch at different spatial scales. The scales analyzed ranged from $50 \mathrm{~m}$ to the total length of the transect $(\sim 25 \mathrm{~km})$ and increased at $100 \mathrm{~m}$ increments. Birds and prey were always clustered at all spatial scales. The average number of 'extra' neighbours of a given individual at a particular spatial scale was also calculated (see O'Driscoll 1998). The scale of aggregation of auklets and prey was defined by the spatial scale at which the average number of 'extra' neighbours first peaked. The density of individuals per prey or auklet aggregation (crowding) was determined by the average number of 'extra' neighbours at the scale of aggregation.

A bivariate $K$ analysis was used to determine whether there were significantly more auklets associated with a given aggregation of prey than would be expected if auklets were distributed randomly (O'Driscoll 1998). For each transect, I calculated the expected number of auklet neighbours to each prey aggregation at a number of spatial scales (see O'Driscoll 1998). The average number of 'extra' auklets at each prey aggregation at each spatial scale was also calculated. The scale of maximum association between auklets and prey was defined by the scale at which the average number of
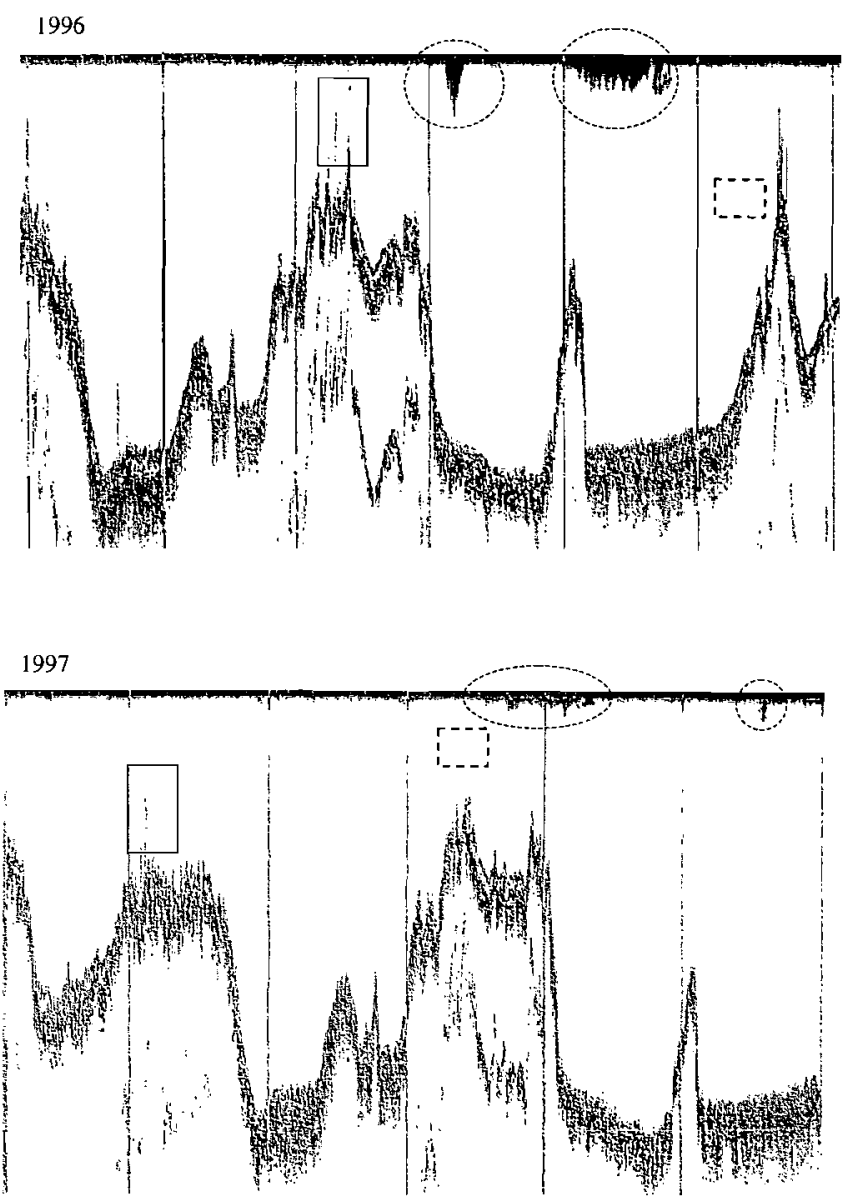

Fig. 2. Echograms recorded in 1996 and 1997 broken up into 5 min time blocks with schools of juvenile Pacific herring indicated within the dashed circles. The schools of herring were netted or visually identified at the ocean's surface. Large fish are indicated within the dashed squares and kelp is indicated within the solid squares 
'extra' auklets first peaked. The density of 'extra' auklets associated with any given prey aggregation (crowding) was determined by the average number of 'extra' auklets at the scale of maximum association. I also calculated a ratio of co-occurrence $\left(R_{\mathrm{o}}\right)$ for auklets and prey to illustrate the proportion of $100 \mathrm{~m}$ blocks in which auklets were located with prey out of the total number of opportunities to be located with prey. The median aggregation scale of auklets and prey, the scale of maximum association and $R_{\mathrm{o}}$ values for each transect were compared between years using singlefactor ANOVAs for unbalanced designs and Scheffe's multiple comparisons test (Sokal \& Rohlf 1995).

Visual observations. Rhinoceros auklets were observed at sea throughout the breeding season in 1996 and during chick-rearing in 1997. One hour instantaneous visual scans of auklets at sea were divided into three 20 min intervals. Scans were conducted during daylight using a spotting scope (see Davoren \& Burger 1999) from a fixed point on land ('observation point'; Fig. 1). The scanning area included the area between the observation point and the breeding colony, which was also covered by the marine transect. I recorded the number of adult auklets engaged in foraging, resting, and maintenance activities throughout the hour. Foraging included solitary diving and flock diving, where a flock was defined as 2 or more auklets diving together. Resting included sitting and swimming on the water. If a bird was resting at the surface between dives, it was considered to be foraging. It was easy to distinguish between resting and recovering from a dive because birds were observed for periods longer than an average dive cycle (see Davoren \& Burger 1999). Maintenance included preening, flapping and bathing. The total number of auklets on the water and associated with feeding flocks, and the number of feeding flocks were also recorded. Auklets diving in a flock, flying and swimming towards or away from a feeding flock, and resting and preening in a dissipated flock were considered to be associated with feeding flocks.

I recorded the dive and inter-dive recovery (pause) durations of auklets diving solitarily to the nearest second in 1996 and 1997. An individual was tracked until it terminated its dive bout, was lost from sight or was confused with other conspecifics. The mean dive and pause durations for different individuals were compared between years using independent sample t-tests.

Analysis of observations. The number of auklets engaged in each activity during each successive 20 min scan was averaged to obtain hourly means. These means were converted into proportions which were square-root and arcsine transformed to meet the underlying assumption of normally distributed data for parametric statistical analysis (Sokal \& Rohlf 1995). The total number of auklets observed on the water and associated with feeding flocks and the number of feeding flocks were averaged to obtain hourly means. Auklets only feed their chicks once each day at night and their behaviour changes while they are collecting fish for delivery to their chicks in the evening during the chick-rearing phase (after 16:00 h; Davoren \& Burger 1999). Consequently, scans conducted after $16: 00 \mathrm{~h}$ during the chick-rearing phase in both years were eliminated from the analysis (1996: $n=33 ; 1997: n=13)$. Two-way ANOVAs for unbalanced design (SYSTAT 1992) were used to compare the hourly means and the transformed proportions among (1) years (1996 and 1997 chick-rearing phases) and (2) time of day categories (before 16:00 and after 16:00 $\mathrm{h}$; presented in = Davoren \& Burger 1999). Independent sample t-tests were used to compare the hourly means and transformed percentages within the 1996 breeding season. The dive and pause durations of solitarily diving auklets did not differ with time of day (Davoren 1997); therefore, all data were used in the analysis. The means are reported with \pm standard error (SE).

\section{RESULTS}

\section{Prey}

The relative abundance of prey in the study area did not differ significantly between years (ANOVA: $F_{2,16}=0.668, \mathrm{p}=0.527$; Table 1). The scale at which prey were aggregated, however, was. significantly different between years $\left(F_{2,16}=9.049, p=0.002\right.$; Table 1), with 1997 being significantly larger than both 1995 (Scheffe's multiple comparison, $p=0.007$ ) and 1996 ( $p=0.004$; Fig. 2). Crowding of prey did not differ significantly among years $\left(F_{2,16}=3.257, \mathrm{p}=\right.$ 0.063 ; Table 1), but 1997 aggregations did not reach similar maximum densities as in previous years (Table 1). This indicates that prey was more dispersed, or less concentrated in patches, throughout the surveyed area in 1997 than in previous years. There was also no difference in prey species or size composition in the area among years, as indicated by fish delivered to chicks of auklets, stomach contents of adults and fish collected at the ocean's surface at mixed-species feeding flocks of seabirds (Davoren \& Burger 1999). Fish species present in the study area included Pacific sand lance Ammodytes hexapterus, Pacific herring Clupea harengus, Pacific salmon species (Oncorhynchus spp.) and surf smelt Hypomesus pretiosus (Davoren \& Burger 1999), all of which are key in the diets of adult auklets and their chicks (Gaston \& Dechesne 1996). 
Table 1 . The mean abundance $( \pm \mathrm{SE})$ of rhinoceros auklets, mean relative abundance $( \pm \mathrm{SE})$ of prey, median and range of the scale of aggregation for auklets and prey $(\mathrm{m})$, the density or number of aggregated auklets (crowding), and the relative density of prey patches (crowding) in 1995, 1996 and 1997

\begin{tabular}{|lcccccc|}
\hline Category & $\begin{array}{c}\text { No. of } \\
\text { transects }\end{array}$ & Abundance & \multicolumn{2}{c}{$\begin{array}{c}\text { Aggregation scale (m) } \\
\text { Range }\end{array}$} & \multicolumn{2}{c|}{$\begin{array}{c}\text { Crowding } \\
\text { Median }\end{array}$} \\
\hline Prey & & & & & \\
1995 & 7 & $0.04 \pm 0.02$ & 850 & $350-1550$ & 1.52 & $0.12-20.40$ \\
1996 & 8 & $0.02 \pm 0.01$ & 750 & $150-950$ & 0.52 & $0.03-16.80$ \\
1997 & 4 & $0.02 \pm 0.01$ & 3600 & $700-7050$ & 0.64 & $0.22-3.20$ \\
Auklets & 7 & $117.3 \pm 22.1$ & 350 & $50-1550$ & 28.2 & $13.4-59.1$ \\
1995 & 8 & $173.5 \pm 34.6$ & 400 & $250-1050$ & 33.6 & $22.8-136.9$ \\
1996 & 4 & $49.5 \pm 9.0$ & 1750 & $1150-1850$ & 34.9 & $19.9-75.5$ \\
1997 & & & & & & \\
\hline
\end{tabular}

In 1996, when observations spanned the entire breeding season, there was a period when fish schools were frequently observed in surface waters during the day ( 13 to 20 June). This period is hereafter referred to as the near-surface prey period.

\section{Birds at sea}

The mean number of auklets encountered during transects differed significantly between years (ANOVA: $F_{2,16}=3.804, \mathrm{p}=0.045$ ), with 1996 having higher numbers than 1997 (Scheffe's multiple comparison, $\mathbf{p}=$ 0.047 ) and 1995, although the latter was not significant $(p=0.335)$. The scale at which auklets were aggregated was significantly different among years $\left(F_{2,16}=\right.$ 14.975, p < 0.0001; Table 1), with 1997 being higher than both 1995 (Scheffe's multiple comparison, $\mathrm{p}=$ $0.001)$ and $1996(p=0.001)$. Crowding of auklets did not differ significantly among years $\left(F_{2,16}=0.352, \mathrm{p}=\right.$ 0.708 ; Table 1). This indicates that there were fewer auklets in the study area and that patches of auklets were dispersed over larger spatial scales in 1997, than in 1996 .

Significantly more auklets were associated with prey aggregations than would be expected if auklets were distributed randomly in all transects. There was no characteristic scale of association; however, there was a significant difference among years (ANOVA: $F_{2,16}=$ 4.228, $\mathrm{p}=0.035$; Table 2), with 1997 having larger scales of maximum association than 1996 (Scheffe's multiple comparison, $\mathrm{p}=0.042$ ) and 1995, although the latter was not statistically significant $(p=0.091)$. The intensity of crowding of auklets at prey aggregations, however, did not differ significantly among years $\left(F_{2,16}=0.388, \mathrm{p}=0.685\right.$; Table 2$) . \mathrm{R}_{\mathrm{o}}$ of auklets and prey was significantly different between years $\left(F_{2,16}=\right.$ 39.573, p < 0.001), with 1996 being significantly higher than both 1995 (Scheffe's multiple comparison, p =
$0.006)$ and 1997 ( $\mathrm{p}<0.0001)$ and with 1995 being significantly higher than 1997 ( $p<0.0001)$.

\section{Time budgets and feeding behaviour}

In the scanned area there were fewer feeding flocks and fewer auklets associated with feeding flocks in 1997, compared to 1996 (Table 3). The percentage of auklets foraging was significantly higher in 1997 compared to 1996, which was due to a significantly higher percentage of auklets diving solitarily in 1997 (Table 3). There was no statistically detectable change in the percentage of auklets engaged in resting and maintenance among years (Table 3 ). The total number of auklets recorded in visual scans throughout the day did not differ significantly between years (Table 3 ).

During the near-surface prey period in 1996, there were more feeding flocks, more auklets associated

Table 2. The median and range of the spatial scale of maximum association between rhinoceros auklets and prey, the density of auklets at prey aggregations (crowding), the range of spatial scales where auklets were significantly associated with prey aggregations, and the mean co-occurrence ratio $\left(\mathrm{R}_{0}\right)( \pm \mathrm{SE})$ of auklets and prey during chick-rearing in 1995, 1996 and 1997

\begin{tabular}{|lccc|}
\hline Category & 1995 & 1996 & 1997 \\
\hline \multicolumn{4}{l}{ Scale of maximum association (m) } \\
Median & 1050 & 650 & 5150 \\
Range & $150-7050$ & $150-4450$ & $2150-11450$ \\
Crowding of auklets at prey aggregations \\
Median & 10.9 & 9.4 & 14.4 \\
Range & $1.6-47.3$ & $1.7-55.0$ & $6.7-32.6$ \\
Range of scales of significant association (m) & \\
50-43150 & $50-18650$ & $550-17050$ \\
Mean co-occurrence ratio (Ro) & $0.7 \pm 0.1$ & $0.9 \pm 0.1$ & $0.4 \pm 0.2$ \\
\end{tabular}


unknown, as physical oceanographic features (temperature, salinity) and biological productivity (primary and secondary production) near my study area remained consistent from January 1995 until March 1997 (Tanasichuk 1998a,b). A severe El Niño, however, began to develop in the Northern Hemisphere in April 1997, which may have caused a variety of conditions, such as the dispersal of fish prey from tight schools, via warm sea surface temperatures (see Mysak 1986, Mann 1993 for review).

Rhinoceros auklets increased the time spent foraging when prey was more dispersed and fewer feeding flocks were observed. In addition, auklets and prey cooccurred less and auklets were less associated with prey when prey was more dispersed. This indicates that auklets spent more time foraging, specifically solitary diving, but were less successful at locating and maintaining contact with prey, when prey was more dispersed in 1997 than in 1996. The higher dispersal of prey probably caused auklets to have lower encounter rates with prey and increased competition among birds at a patch due to the lower densities of prey per patch. This was supported by fewer auklets in the study area and aggregations of auklets being dispersed over larger spatial scales in 1997 than in 1996. The lower maximum densities of prey per patch may be critical to diving birds because they exhibit threshold foraging behaviour (Piatt 1990), suggesting that large patches are essential for efficient foraging (Gaston \& Jones 1998). Overall, higher competition may have caused auklets to search for unattended prey patches, suppressing their ability cue to the foraging activities of other birds (local enhancement).

Auklets also increased the time spent foraging, specifically by flock diving, when prey was readily available during near-surface prey periods. Auklets collect fish for themselves, rather than for delivery to their chicks, when diving in mixed-species feeding flocks (Davoren \& Burger 1999); therefore, this increase in time spent foraging represents an increase in selffeeding. Energy demands are highest when seabirds are rearing chicks because parents must collect food for themselves and their chicks (Drent \& Dann 1980). Searching for prey involves energetically expensive activities, the most expensive of which is flight (Pennycuick 1987). The wing design of alcids is a compromise between efficient underwater flight (low surface area) and aerial flight (high surface area; Pennycuick 1987) and, thus, aerial flight is more costly for alcids relative to other seabirds. Seabirds are known to make many energy state-dependent foraging decisions while rearing chicks and fluctuations in adult body mass appear to drive these foraging/provisioning decisions (e.g. Chaurand \& Weimerskirch 1994, Weimerskirch et al. 1997, Weimerskirch 1998). Consequently, the increase in time spent foraging at mixed-species feeding flocks without an increase in energetically expensive search activities may provide an opportunity for adults to maintain energy stores and, thereby, minimize the risk of starvation if foraging conditions decline.

Pause durations, or recovery periods between successive dives in a foraging bout, decreased in 1997. while dive durations remained unchanged. This suggests that auklets postponed full recovery from the physiological effects of diving until foraging bouts were finished (Kooyman 1989, Houston \& Carbone 1992). Common murres also reduced recovery periods between dives when foraging conditions declined in Scotland (Monaghan et al. 1994). Postponing full recoveries after dives was suggested to be advantageous when birds locate a temporally ephemeral prey patch because prey may escape between dives (Ydenberg 1988, Ydenberg \& Forbes 1988). In 1997, the reduction in recovery periods may reflect a greater urgency to take advantage of prey in a patch once it was located because it was more difficult to locate prey compared to previous years. Overall, auklets worked harder while foraging in 1997, presumably to increase underwater search times and encounter rates with prey, or foraging success, once a patch was located.

\section{Behavioural responses of auklets to variable prey distribution}

In general, auklets appeared to use mixed-species feeding flocks as a supplementary foraging method to solitary foraging, because solitary diving was more common than flock diving under most environmental conditions (Sealy 1973, this study). Animals that exploit unpredictable food sources may benefit from using a combination of group and solitary foraging under varying environmental conditions (e.g. Ryer \& Olla 1995). The energy budget rule of risk-sensitive foraging theory (Caraco 1981) states that if a forager expects to exceed its required energy intake throughout a day, it should choose a constant food source and avoid the chances of doing poorly at a variable food source ('risk-averse' strategy). In contrast, if a forager does not expect to meet its required energy intake, it should choose the more variable food source and accept the risk of doing very poorly for the chance to do very well ('risk-prone' strategy). Social foraging is thought to be a risk-averse strategy because it reduces variation in energy intake (Clark \& Mangel 1984, 1986, Eckman \& Hake 1988). Therefore, an animal should switch between social foraging (risk-averse) and solitary foraging (risk-prone) as prey conditions change.

During near-surface prey periods, there were more feeding flocks and more auklets associated with feed- 
ing flocks. This indicates that auklets responded to the higher accessibility and clumped distribution of their prey by shifting their foraging behaviour. Taking advantage of a readily available prey source at feeding flocks likely reduced the variation in foraging success of auklets, thereby minimizing the long-term risk of starvation (risk-averse; Ekman \& Hake 1988, Flemming et al. 1992). In contrast, in 1997, when prey was more dispersed, fewer feeding flocks were formed and fewer auklets were associated with flocks. Solitary foraging likely maximized the variation in foraging success, allowing sufficiently high prey encounter rates (riskprone; Brown 1988). Therefore, the variable use of solitary and flock foraging under changing prey conditions qualitatively supports the energy budget rule. In addition, even though seabirds may benefit from joining mixed-species feeding flocks, infrequent encounters with surface schools and concentrated patches of prey in 1997 appeared to create conditions under which flock foraging was difficult or unprofitable.

\section{Behavioural flexibility}

Rhinoceros auklets appeared to be able to adjust their foraging behaviour and time budgets under varying levels of prey concentration. In 1997 auklets increased the time spent foraging and incorporated a higher degree of solitary foraging when prey was more dispersed. These behavioural adjustments probably allowed auklets to maintain the growth of nestlings at a similar rate among years in this study (Davoren 1997). Growth rates of rhinoceros auklets in this study were also similar to other studies (see Gaston \& Dechesne 1996). Overall, flexible foraging behaviour and time budgets are probably important characteristics of seabird life history, due to the high temporal and spatial variability of pelagic prey.

There is much evidence for behavioural flexibility in seabirds and other birds. First, studies report a high percentage of resting at the colony during daylight hours in the time budgets of breeding seabirds (common murres: $32 \%$, Wanless et al. 1985; $22 \%$, Burger \& Piatt $1990 ; 2$ to $40 \%$, Uttley et al. 1994; thick-billed murres: $24 \%$, Gaston \& Nettleship 1981; $24 \%$, Furness \& Barrett 1985). Studies also show that breeding seabirds have a high percentage of non-foraging time at sea (common murres: 79 to $83 \%$, Cairns et al. 1987 ; 70 to $85 \%$, Cairns et al. $1990 ; 82 \%$, Monaghan et al. 1994; rhinoceros auklets: 77 to $96 \%$, this study). Second, flexibility in daily time budgets has been shown for many seabirds through decreased resting times at the colony or increased durations of foraging trips when food supplies were reduced (Burger \& Piatt 1990 , Monaghan et al. 1996). The present study also showed flexibility in the time spent foraging and resting throughout the day under varying foraging conditions. Overall, the degree to which birds approach their maximum work capacity probably influences their ability to adjust time budgets (Herbers 1981, Southern \& Moss 1985) and subsequently buffers the deleterious effects of poor foraging conditions on breeding success and adult survival.

In conclusion, the time budgets and foraging behaviour of rhinoceros auklets appeared to be sensitive to moderate fluctuations in foraging conditions. This emphasizes the importance of examining the time buffering capabilities of seabirds (Burger \& Piatt 1990), as well as foraging behaviour, when designing studies to test their ability to indicate changing oceanic conditions (Cairns 1987). This study also emphasizes the importance of behavioural flexibility when living in a highly variable environment. Overall, adjusting the amount of group and solitary foraging along with the time spent foraging allowed auklets to breed successfully when faced with varying levels of competition and shifting prey availability.

Acknowledgements. 1 thank A. E. Burger for scientific support and for comments on this manuscript. I also thank Leslie Paul for planning, building and maintaining the 1996 field camp. I thank D. Ney, K. Paul, J. Davoren and B. Davoren for assistance with field work. l also gratefully acknowledge $R$. O'Driscoll for help with data analysis. I am thankful for the technical support and equipment loans from N. Mathews, Cape Beale light station attendants, B.C. Ministry of Environment, Canadian Wildlife Service, Bamfield Marine Station and Parks Canada (Pacific Rim National Park). This study was supported by a NSERC Canada Post Graduate Scholarship (A) to G.K.D., a NSERC Operating Grant to A. E. Burger, John K. Cooper Foundation, Bamfield Marine Station, NSERC/ CSW Wildlife Ecology Research Chair, Nestucca Fund and the James L. Baillie Memorial Fund of the Long Point Bird Observatory and Bird Studies Canada.

\section{LITERATURE CITED}

Brown CR (1988) Social foraging in cliff swallows: local enhancement, risk sensitivity, competition and the avoidance of predators. Anim Behav 36:780-792

Burger AE (1997) Arrival and departure behavior of common murres at colonies: evidence for an information halo. Colon Waterbirds 20:55-65

Burger AE, Piatt JP (1990) Flexible time budgets in common murres: buffers against variable prey abundance. Stud Avian Biol 14:71-83

Cairns DK (1987) Seabirds as indicators of marine food supplies. Biol Oceanogr 5:261-271

Cairns DK, Bredin KA, Montevecchi WA (1987) Activity budgets and foraging ranges of breeding common murres. Auk 104:218-224

Cairns DK, Montevecchi WA, Birt-Friesen VL, Macko SA (1990) Energy expenditures, activity budgets, and prey harvest of breeding common murres. Stud Avian Biol 14: $84-92$ 
Caraco T (1981) Energy budgets, risk and foraging preferences in dark-eyed juncos (Junco hyemalis). Behav Ecol Sociobiol 8:213-217

Chaurand T, Weimerskirch $H$ (1994) The regular alternation of short and long foraging trips in the blue petrels Haloaena caerulea: a previously undescribed strategy of food provisioning in a pelagic seabird. J Anim Ecol 63 $275-282$

Clark CW, Mangel M (1984) Foraging and flock strategies: information in an uncertain environment. Am Nat 123 626-641

Clark CW, Mangel, M (1986) The evolutionary advantages of group foraging. Theor Pop Biol 30:45-75

Davoren GK (1997) Parental investment in rhinoceros auklets (Cerorhinca monocerata) at the colony and at sea off southwestern Vancouver Island. MSc thesis, University of Victoria

Davoren GK, Burger AE (1999) Differences in prey selection and behaviour during self-feeding and chick provisioning in rhinoceros auklets. Anim Behav 58:853-863

Drent $\mathrm{RH}_{4}$ Daan S (1980) The prudent parent: energetic adjustments in avian breeding. Ardea 68:225-252

Ekman J, Hake M (1988) Avian flocking reduces starvation risk: an experimental demonstration. Behav Ecol Sociobiol 22:91-94

Flemming SP, Smith PC, Seymour NR, Bancroft RP (1992) Ospreys use local enhancement and flock foraging to locate prey. Auk 109:649-654

Furness RW, Barrett RT (1985) The food requirements and ecological relationships of a seabird community in north Norway. Ornis Scand 16:305-313

Gaston AJ, Dechesne SBC (1996) Rhinoceros auklet (Cerorhinca monocerata). In: Poole A, Gill F (eds) The birds of North America (no. 212). Academy of Natural Sciences, Philadelphia, and American Ornithologists' Union, Washington, $\mathrm{DC}, \mathrm{p}$ 1-20

Gaston AJ, Jones IL (1998) The auks. Oxford University Press, New York

Gaston AJ, Nettleship DN (1981) The thick-billed murres of Prince Leopold Island. Can Wildl Serv Monogr Ser 6, Ottawa

Harrison NM, Whitehouse MJ, Heinemann D, Prince PA, Hunt GL Jr, Veit RR (1991) Observations of multispecies seabird flocks around South Georgia. Auk 108:801-810

Herbers JM (1981) Time resources and laziness in animals. Oecologia 49:252-262

Hoffman W, Heinemann D, Wiens JA (1981) The ecology of seabird feeding flocks in Alaska. Auk 98:437-456

Houston AI, Carbone C (1992) The optimal allocation of time over the dive cycle. Behav Ecol 3:255-265

Kooyman GL (1989) Diverse divers: physiology and behaviour. Springer-Verlag, London

Mann KH (1993) Physical oceanography, food chains, and fish stocks: a review. ICES J Mar Sci 50:105-119

McNamara JM, Houston AI (1985) Optimal foraging and learning. J Theor Biol 117:231-249

Monaghan P, Walton P, Wanless S, Uttley JD, Burns MD (1994) Effects of prey abundance on the foraging behavjour, diving efficiency and time allocation of breeding Guillemots Uria aalge. Ibis 136:214-222

Monaghan P, Wright PJ, Bailey MC, Uttley JD, Walton $\mathrm{P}$, Burns MD (1996) The influence of changes in food abundance on diving and surface-feeding seabirds. In: Montevecchi WA (ed) Studies of high-latitude seabirds. 4. Trophic relationships and energetic of endotherms in cold ocean systems. Can Spec Publ Fish Aquat Sci 91:10-19

Mysak L.A (1986) El Niño, interannual variability and fisheries in the Northeast Pacific Ocean. Can J Fish Aquat Sci 43: 464-497

O'Driscoll RL (1998) Description of spatial pattern in seabird distributions along line transects using neighbour $K$ statistics. Mar Ecol Prog Ser 165:81-94

Pennycuick CJ (1987) Flight of seabirds. In: Croxall JP (ed) Seabirds: feeding ecology and role in marine ecosystems. Cambridge University Press, Cambridge, p 43-62

Piatt JF (1990) The aggregative response of common murres and atlantic puffins to schools of capelin. Stud Avian Biol $14: 36-51$

Porter JM, Sealy SG (1981) Dynamics of seabird multispecies feeding flocks: chronology of flocking in Barkley Sound, British Columbia, in 1979. Colon Waterbirds 4:104-113

Porter JM, Sealy SG (1982) Dynamics of seabird multispecies feeding flocks: age-related feeding behaviour. Behaviour 82:91-109

Ryer CH, Olla BL (1995) Influences of food distribution on fish foraging behaviour. Anim Behav 49:411-418

Sealy SG (1973) Interspecific feeding assemblages of marine birds off British Columbia. Auk 90:796-802

Shettleworth SJ, Krebs JR, Stephens DW, Gibbon J (1988) Tracking a fluctuating environment: a study of sampling. Anim Behav 36:87-105

Sokal RR, Rohlf FJ (1995) Biometry. WH Freeman and Company, New York

Southern WJ, Moss D (1985) The inactivity of amimals: influence of stochasticity and prey size. Behaviour 92:1-8

SYSTAT (1992) SYSTAT for Windows: statistics, Version 5. Evanston, IL

Tanasichuk RW (1998a) Interannual variations in the population biology and productivity of Euphausia pacifica in Barkley Sound, Canada, with special reference to the 1992 and 1993 warm ocean years. Mar Ecol Prog Ser 173:163-180

Tanasichuk RW (1998b) Interannual variations in the population biology and productivity of Thysanoessa spinifera in Barkley Sound, Canada, with special reference to the 1992 and 1993 warm ocean years. Mar Ecol Prog Ser 173 181-195

Tasker ML, Jones PH, Dixon T, Blake BF (1984) Counting seabirds at sea from ships: a review of methods employed and a suggestion for a standardized approach. Auk 101: 567-577

Uttley JD, Walton P, Monaghan P, Austin G (1994) The effect of food abundance on breeding performance and adult time budgets of guillemots Uria aalge. Ibis 136:205-213

Wanless S, Harris MP, Morris JA (1985) Radio-monitoring as a method for estimating time budgets of Guillemots Uria aalge. Bird Study 32:170-175

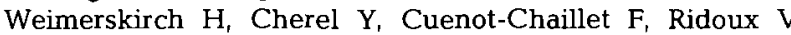
(1997) Alternative foraging strategies and resource allocation by male and female wandering albatrosses. Ecology 78:2051-2063

Weimerskirch $\mathrm{H}$ (1998) How can a pelagic seabird provision its chick when relying on a distant food resource? Cyclic attendance at the colony, foraging decision and body condition in sooty shearwaters. J Anim Ecol 67:99-109

Wittenberger JF, Hunt GL Jr (1985) The adaptive significance of coloniality in birds. In: Farner DS, King JR, Parkes KC (eds) Avian biology, Vol 8. Academic Press Inc, Toronto, p 1-77

Ydenberg RC (1988) Foraging by diving birds. In: Ouellet $\mathrm{H}$ (ed) Acta XIX Congressus Internationalis Ornithologici, Ottawa, Ontario (1986). National Museum of Natural Science, Ottawa, p 1832-1842

Ydenberg RC, Forbes LS (1988) Diving and foraging in Western Grebes. Ornis Scand 19:129-133

Submitted: February 1, 1999; Accepted: December 2, 1999

Proofs received from author(s): May 4, 2000 